\title{
PEMODELAN LEVEL ENERGI DISKRET PADA SEL SURYA KUANTUM DOT DAN WELL BERBASIS MATERIAL NANOSTRUKTUR
}

\author{
Hubertus Ngaderman, Ego Srivajawaty
}

Universitas Cendrawasih

Email: ngadermanh@gmail.com

\begin{abstract}
ABSTRACK
The aim of this research is to finding out modeling nanostructure solar cell SC with count in electron energy level on the conduction band. Divais photovoltaic nano i.e quantum dot $Q D$ and quantum well $Q W$ performing wide range transition of electron which can be controlled by the distribution range area suitably of the size dimension $Q D$. QD gives ability absorbance of the ligth where created electron hole coupling which located in the dot. Transition electron in the $Q D$ be significant exceed thermal energy and cannot inducted by the fonon thermally while transition hole be simply inducted by the phonon acoustik thermal.

Method of this research are concept and computation for accounting energy level. The concept which be used is DEK. The thickness well $L_{w}$ is small enough (10 nm or less), the set of level energy discret will be in the well and have hinges at the effective mass and the well thickness i.e $E_{n}$ rising with reduction $m^{*}$ or $L_{w}$. Maximum energy $E_{1}=$ $3,77 \times 10^{4} \mathrm{eV}$ at the thickness layer $L_{w}=0,1 \mathrm{~nm}$. Maximum energy $E_{2}=1,51 \times 10^{5} \mathrm{eV}$ at the $L_{w}=0,1 \mathrm{~nm} . \Delta E$ is difference magnitude energy in the starting point $0,1 \mathrm{~nm}$ i.e $1,13 \times 10^{5} \mathrm{eV}$ and in the last thickness $Q \mathrm{~W}$ i.e $10 \mathrm{~nm}$ is $1,13 \times 10^{1} \mathrm{eV}$. Therefore transition electron in the $Q W$ be significantly exceed thermal energy and cannot inducted by the phonon thermal.
\end{abstract}

Keywords: nanostructure solar cell SC; quantum dot $Q D$; quantum well $Q W$

\section{PENDAHULUAN}

Nanoteknologi adalah kontrol materi pada dimensi 1 sampai 100 nanometer, dimana fenomena unik memampukan aplikasi terbaru mencakup sains dan teknologi yang melibatkan imaging, pengukuran, modeling dan manipulasi materi pada skala ini. Ia bukan sesuatu yang baru dan terpisahkan dengan alam, partikel emas skala nano menciptakan corak warna berbeda ditemukan di abad pertengahan. Partikel emas mempertunjukkan sebuah bentuk yang berbeda warna bergantung pada ukuran pada skala nano. Materi pada skala atomik berkelakuan sangat berbeda daripada materi pada saat skala makroskopik. Juga kemampuan untuk membangun materi baru pada suatu saat membuka kemungkinan baru ke depan yang dikembangkan menggunakan proses kimia tradisional.

Kemampuan struktur pita, mempertinggi multiplikasi carrier dan nano-plasmonik untuk perbaikan efisiensi SS. Nanoteknologi menyediakan banyak kemungkinan dalam merekayasa maupun memanipulasi, kekurangannya adalah mempertinggi proses rekombinasi maka mengurangi waktu tempuh fotopembawa. Waktu tempuh adalah besaran yang sensitif, menurunkan ia maka efisiensinya menjadi rendah. Sel dengan impuritas diharapkan mempunyai efisiensi $77 \%$, tetapi malah mempertinggi rekombinasi dan memperburuk performansi. Rekombinasi yang hilang karena hal tersebut adalah masalah jangka panjang tanpa keberhasilan yang nyata didalam investigasi. SS nanostruktur telah diteliti secara intensif selama dekade terakhir, intermediate dibentuk dari level kuantum dot (KD) atau well diskret karena penerowongan kuat kopeling diantara KD. Pembuatan KD secara khas didalam ukuran antara 5 dan $50 \mathrm{~nm}$, ditetapkan oleh lithografi gerbang elektroda atau oleh pengetsaan pada dua dimensi gas elektron didalam semikonduktor heterostruktur yang bisa mempunyai dimensi lateral antara 20 dan $100 \mathrm{~nm}$. KD kadang-kadang terjadi secara spontan didalam struktur kuantum well menyebabkan fluktuasi monolapisan didalam ketebalan well. Teori bisa memberikan efisiensi maksimum $\sim 65 \%$ tetapi eksperimen menunjukkan kenaikannya tidak melampaui beberapa persen oleh karena KD.

Analisis teoritis dan modeling akan dilakukan didalam menghitung level energi 
elektron didalam pita konduksi. Model yang digunakan untuk memahami mekanisme kerja SS nanostruktur adalah Divais Efek Kuantum (DEK). Untuk ketebalan kuantum well atau dot direkayasa didalam bentuk yang bersesuaian dengan eksperimen. Tujuan penelitian ini adalah mendapatkan pemodelan SS nanostruktur dengan menghitung level energi elektron yang terjadi pada pita konduksi.

\section{METODOLOGI PENELITIAN}

Metode dalam penelitian ini menggunakan konsep dan komputasi untuk menghitung level energi. Konsep yang digunakan adalah Divais Efek Kuantum (DEK), ia adalah divais dasar yang menggambarkan SS nanostruktur. DEK menggunakan penerowongan mekanika kuantum untuk memberikan kontrol transpor pembawa, ketebalan lapisan aktifnya adalah sangat kecil pada orde $10 \mathrm{~nm}$. Dasar dari DEK adalah Penerowongan Dioda Resonan (PDR).

Gambar 1 menunjukkan diagram pita dari DEK, dia mempunyai struktur dobel barier semikonduktor yang berisi dua heterojunktion dan satu kuantum well, InAs/GaAs/InAs . Terdapat tiga parameter divais yang penting untuk PDR - tinggi energi barier $E_{0}$ dimana adalah diskontuinitas pita konduksi, ketebalan energi barier $L_{B}$ dan ketebalan kuantum well $L_{w}$. Jika ketebalan well $L_{w}$ adalah cukup kecil (pada orde $10 \mathrm{~nm}$ atau kurang), set level energi diskret akan ada didalam well $\left(E_{1}, E_{2}, E_{3}\right.$ dan $\left.E_{4}\right)$. Jika ketebalan barier adalah begitu kecil, penerowongan resonan akan terjadi. Ketika elektron datang mempunyai energi $E$ yang secara pasti sama dengan level energi diskret didalam well dia akan menerobos melalui dobel barier dengan kesatuan $100 \%$ koefisien transmisi.

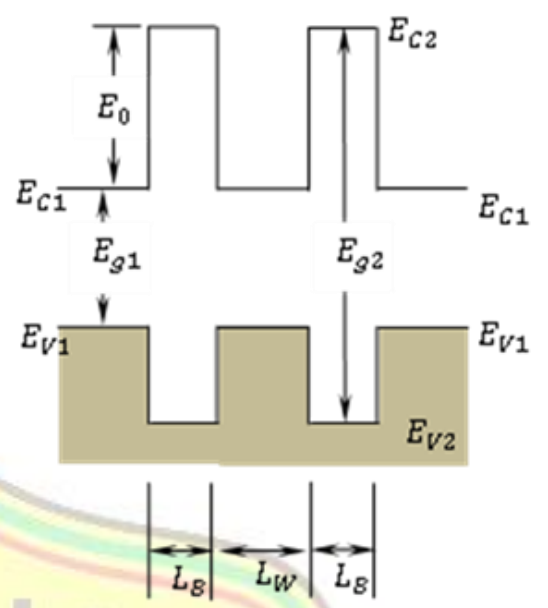

Gambar 1. Diagram pita dari Divais Efek Kuantum (DEK).

Koefisien transmisi berkurang secara cepat sebagai penyimpangan level energi diskret. Sebagai contoh elektron dengan energi $10 \mathrm{meV}$ lebih tinggi atau lebih rendah daripada level $E_{1}$ akan ada $10^{5}$ kali penurunan didalam koefisien transmisi. Koefisien transmisi bisa dihitung dengan penyelesaian persamaan Schroedinger satu dimensi didalam tiga daerah (I, II, III). Oleh karena fungsi gelombang dan derivatif pertama mereka pada masing-masing diskontuinitas potensial harus kontinu, kita bisa mendapatkan koefisien transmisi $T_{t}$.

Persamaan Schroedinger untuk elektron didalam suatu wilayah dapat ditulis

$$
-\frac{\hbar^{2}}{2 \mathrm{~m}_{\mathrm{i}}^{*}}\left(\frac{\mathrm{d}^{2} \psi_{\mathrm{i}}}{\mathrm{dx}^{2}}\right)+\mathrm{V}_{\mathrm{i}} \psi_{\mathrm{i}}=\mathrm{E} \psi_{\mathrm{i}} \quad \mathrm{i}=1,2,3
$$

dimana $\hbar$ konstanta Planck tereduksi, $m_{i}^{*}$ massa efektif didalam daerah $i, E$ energi datang dan $V_{i}$ adalah potensial energi dan $\psi_{i}$ fungsi gelombang didalam daerah $i$ berturut-turut. Fungsi gelombang $\psi_{i}$ bisa dinyatakan sebagai

$$
\psi_{i}(x)=A_{i} \exp \left(j k_{i} x\right)+B_{i} \exp \left(-j k_{i} x\right)
$$

dimana $A_{i}$ dan $B_{i}$ adalah konstantakonstanta ditentukan dari kondisi bidang batas dan

$$
k_{i}=\sqrt{2 m_{i}^{*}\left(E-V_{i}\right)} / \hbar
$$

Oleh karena fungsi gelombang dan derivatif pertama mereka adalah

$$
\frac{\psi_{i}}{m_{i}^{*}}=\frac{\psi_{i+1}}{m_{i+1}^{*}}
$$


Seperti estimasi orde pertama dari level energi, kita bisa menggunakan kuantum well dengan ketinggian barier tak hingga:

$$
E_{n}=\left(\frac{\pi^{2} \hbar^{2}}{2 m^{*} L_{w}^{2}}\right) n^{2} .
$$

Untuk sebuah struktur barier dobel dengan ketinggian barier terbatas dan lebar, level energi akan lebih rendah, bagaimanapun juga, dia akan mempunyai pergantungan yang serupa pada massa efektif dan ketebalan well yaitu $E_{n}$ meningkat dengan pengurangan $m^{*}$ atau $L_{w}$. Diagram alir untuk melakukan penelitian ini adalah:

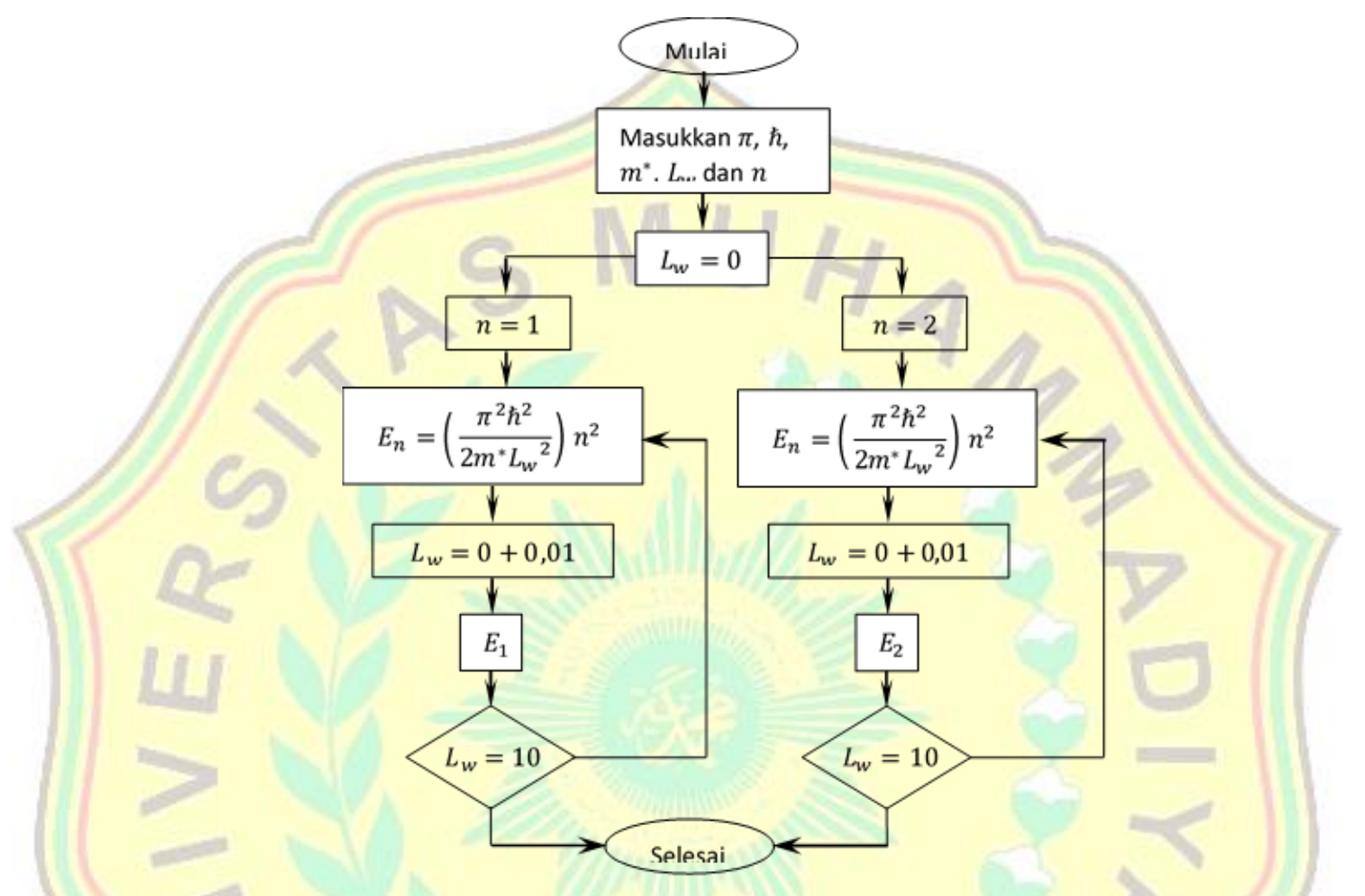

\section{HASIL DAN PEMBAHASAN}

Gambar 3 adalah grafik untuk menghitung tingkat pertama dari energi pada kuantum well (KW) yaitu $E_{1}$ dengan ketebalan lapisan $\mathrm{KW}$ yaitu $L_{w}$. Gambar 4 adalah grafik untuk menghitung tingkat kedua dari energi pada $\mathrm{KW}$ yaitu $E_{2}$ dengan ketebalan lapisan KW yaitu $L_{w}$. Energi maksimum $E_{1}=3,77 \times 10^{4} \mathrm{eV}$ pada ketebalan lapisan $-L_{w}=0,1 \mathrm{~nm}$. Energi maksimum $E_{2}=1,51 \times 10^{5} \mathrm{eV}$ pada ketebalan

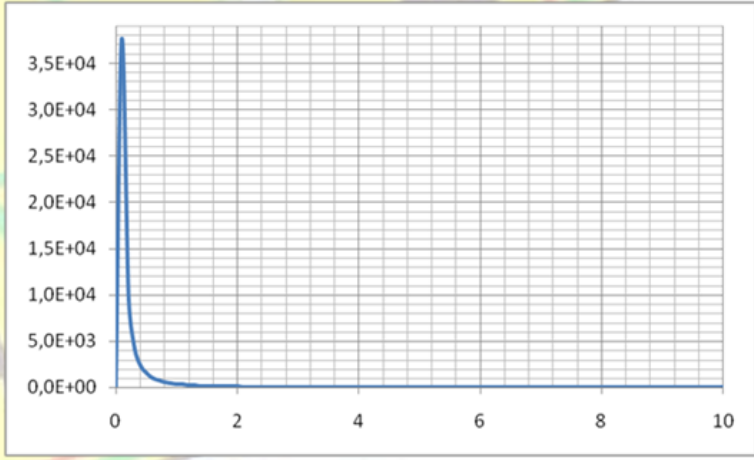

Gambar 3. Grafik untuk menghitung tingkat pertama energi pada kuantum well (KW) yaitu $E_{1}$ dengan ketebalan lapisan KW yaitu $L_{w}$. 


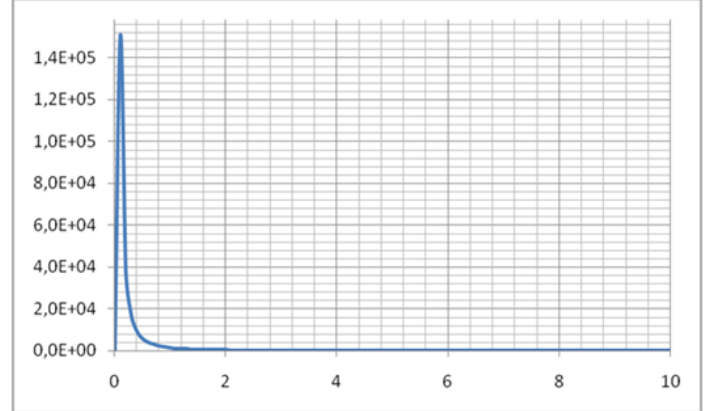

Gambar 4. Grafik untuk menghitung tingkat kedua energi pada kuantum well $(\mathrm{KW})$ yaitu $E_{2}$ dengan ketebalan lapisan KW yaitu $L_{w}$.

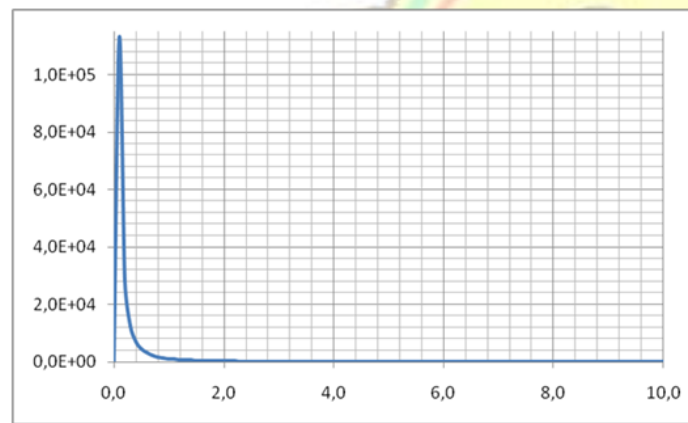

Gambar 5. Grafik untuk menghitung selisih antara tingkat energi kedua $E_{2}$ dengan $E_{1}$.

Gambar 5 adalah grafik untuk menghitung selisih $\Delta E=E_{2}-E_{1}$ antara tingkat energi kedua $E_{2}$ dengan $E_{1}$. Dari grafik pada Gambar 5 terlihat bahwa selisih tersebut untuk ketebalan lapisan mula-mula yaitu diperkirakan di titik maksimum (sebab pada titik tersebut terdefinisikan suatu besar dari energinya walaupun ada suatu nilai di titik awalnya) $0,1 \mathrm{~nm}$ adalah $1,13 \times 10^{5} \mathrm{eV}$, dan di ketebalan akhir pada KW yaitu $10 \mathrm{~nm}$ adalah $1,13 \times 10^{1} \mathrm{eV}$. Oleh karena itu transisi elektron didalam KW secara berarti melampaui energi termal dan tidak bisa diinduksi oleh fonon termal.

\section{KESIMPULAN DAN SARAN}

KW memberikan kemampuan tinggi didalam menyerap cahaya dimana menciptakan pasangan elektron hole yang terlokasi didalam well. Menggunakan model diatas maka level energi $\Delta E$ di pita konduksi memiliki nilai melampaui energi termal dan tidak bisa diinduksi oleh fonon termal oleh karena itu proses tangkapan menjadi sangat efektif sehingga KW menjadi nanomaterial yang berguna untuk meningkatkan performansi sel.

Belum dihitung level energi untuk hole $\Delta E_{h}$, semoga penelitian berikutnya oleh penulis maupun peneliti lainnya bisa menghitungnya dan memodelkan level energi tersebut baik pada pita valensi maupun pada pita konduksi jika ada. Membuat SS nanomaterial merealisasikannya model tersebut didalam piranti SS KW dan KD yang nyata.

\section{DAFTAR PUSTAKA}

DeVries.P.L. A First Course in Computational Physics. John Wiley and Sons.

\section{Jogiyanto H.M, 1998. Dasar-dasar Pemrograman Pascal. Andi Offset,Yogyakarta.}

Krane K, 1996. Fisika Modern. John Wiley and Sons.

Pauling L, 1935, Introduction to Quantum Mechanics. McGraw-Hill Company, INC.

Sablon K A., Sergeev A, 2014, Emerging PV Nanomaterials: Capabilities Versus Recombination Losses. Springer Series in Materials Science.

Sze S.M., 2003. Physics of Semiconductor Devices 2nd edition. John Wiley and Sons.

Quiñonez A, 2008, Introduction to Nanotechnology. Electronics and Advanced Technologies Austin Community College.

Wang Z, Zhiming M.W, 2014, High Efficiency Solar Cell. Springer Series in Materials Science. 